\title{
ANALYSIS OF CHANGES IN MUNICIPAL WASTE MANAGEMENT AT THE COUNTY LEVEL
}

\author{
Grzegorz Przydatek ${ }^{1}$, Anna Kochanek' ${ }^{1}$, Magdalena Basta ${ }^{1}$ \\ 1 Institute of Technology, State Higher Vocational School in Nowy Sącz, Staszica 1, 33-300 Nowy Sącz, Poland, \\ e-mail: gre94@wp.pl
}

Received: 2016.10.01

Accepted: 2016.10.23

Published: 2017.01.01

\begin{abstract}
The objective of the study was to identify system changes in waste management, including qualitative and quantitative changes in the Łososina Dolna County between 2012 and 2014, taking into account eleven waste streams in the period before and after the introduction of these changes on the level of the county. Differences in the county's tasks with respect to municipal waste management, which became clear after the changes, were shown along with their impact on the effectiveness of the assigned tasks related to taking over the obligations of waste collection by property owners. On this basis, a $10 \%$ growth in the quantity of collected municipal waste was noticed after the changes, as well as a $4 \%$ growth in recycled materials, in particular plastic. A drop on the level of $8.5 \%$ in the collected mixed municipal waste was considered favourable; however, a drop in the share of glass waste amounting to $5.28 \%$ and was considered as negative. In spite of the introduced changes in the municipal waste stream, the share of non-segregated waste of over $67.55 \%$ remained significant. The year of changes was characterised by relatively low value of waste accumulation index on the level of $0.26 \mathrm{~kg} \cdot \mathrm{M}^{-1} \cdot \mathrm{day}^{-1}$. The aim of the study was to assess the efficiency of municipal waste management in the Lososina Dolna County in comparison to system changes in waste management introduced at the end of the first and the beginning of the second half of 2013.
\end{abstract}

Keywords: waste management, household waste, recovery

\section{INTRODUCTION}

At present, waste and waste-related threats constitute a grave problem in the area of environmental protection. The main sources of municipal waste are households and infrastructural facilities, such as trade, industry, services and education. The place of waste generation, affluence of the society, as well as consumption models determine the morphological composition and the quantity of municipal waste [Rosik-Dulewska, 2015]. Waste is an economic, social, environmental and often an aesthetic problem. Presently, when environmental threats depend mainly on the amounts of various types of waste, it is necessary to implement activities encompassing: accumulation, transport and neutralisation of waste [Leboda and
Oleszczuk, 2002]. Simultaneously, such activities should not cause damage to the environment [Biegańska and Ciuła, 2011]. Statutory changes in waste management which took place in the recent years are aimed at reducing the amount of generated municipal waste and waste deposited at landfill sites. Waste management, in line with the provisions applicable in Poland, belongs to the own tasks of each county [Kwapisz, 2005]. Maintenance of order and cleanness related to it influences environmental protection, protection of health and care for the aesthetics and order [Rakoczy, 2013]. The obligation of collecting municipal waste by counties from real property owners and imposing fees for waste management is aimed to support improved waste management [Przydatek, 2012]. In this aspect, it is important 
to recognize the course of changes in waste management on the county level, both on the basis of analysis of legal regulations and the results of collected waste in two different study periods.

\section{STUDY OBJECTIVE AND METHODOLOGY}

The objective of the study was to evaluate municipal waste management efficiency in the Łososina Dolna County in relation to the system changes in waste management introduced at the end of the first and the beginning of the second half of 2013. The study discusses issues related to statutory changes and the effects of their implementation in municipal waste management in a selected county in the Małopolska province.

The data that was accepted for analysis derives from the Central Statistical Office and the Łososina Dolna County. The object of analysis was to determine the direction of quantitative and qualitative changes in the municipal waste collected in a selective and non-selective manner in the area of the Lososina Dolna County between 2012 and 2014, taking into account the period before and after the introduction of the system changes, as well as the number of inhabitants and households. Waste collected selectively included: glass, plastic materials, paper and cardboard (including packaging). Furthermore, the object of the analysis encompassed used electric and electronic devices, products containing CFC, fluorescent lamps and other waste types containing mercury, batteries and bio-degradable waste, other non-biodegradable waste, including waste from municipal cemeteries, mixed waste containing concrete, brick rubble, ceramic materials and interior design elements.

On the basis of the amount of collected waste, the index of mass accumulation of waste on a daily basis was determined.

\section{CHARACTERISTICS OF THE ŁOSOSINA DOLNA COUNTY}

The Lososina Dolna County is located in the Nowy Sącz Poviat in the Małopolska Province. It lies in the eastern section of the Beskid Wyspowy mountains and covers a significant portion of the Lososina Range with numerous hills. With respect to height, Jaworz (921 metres above sea level), Chelm (789 metres above sea level) and Góra Św. Justa (484 metres above sea level) are characteristics in the area. The last one separates the county into two valleys: the Łososina and the Dunajec [Łososina Dolna County, 2015].

The Łososina River flows through a major part of the county; it ends its course in Lake Czchów. The eastern border of the county is designated by Lake Rożnów [Łososina Dolna County, 2015]. Main Underground Reservoir 435 - the Dunajec River Valley is located in the county.

The surface area of the county amounts to 84 square kilometres and constitutes $5.4 \%$ of the Nowy Sącz Poviat. The commune consists of nineteen villages (Białawoda, Bilsko, Łęki, Łososina Dolna, Łyczanka, Michalczowa, Rąbkowa, Rojówka, Skrzętla, Stańkowa, Świdnik, Tabaszowa, Tęgoborze, Witowice Dolne, Witowice Górne, Wronowice, Zawadka, Znamirowice, Żbikowice) [Łososina Dolna County, 2015].

The Białawoda Góra nad Dunajcem Nature Reserve is located in this area with a surface of 67.69 hectares; it encompasses a Carpathian beech forest and oak forest with rock plants, including protected species such as globeflower (Trollius europaeus) and Martagon lily (Lilium martagon). Furthermore, the area of the county features the Southern Małopolska Protected Landscape Site and eight nature monuments. The county has brown acidic soils, leached, skeleton, clayey and alluvial soils [Łososina Dolna County, 2015].

\section{ANALYSIS OF SYSTEM CHANGES IN WASTE MANAGEMENT ON COUNTY LEVEL}

\section{Analysis of municipal waste management system until 30 June 2013}

Until 30 June 2013, the municipal waste management system in the county functioned in line with the local law which was determined by the Regulation on Maintaining Cleanness and Order in the Lososina Dolna County [Regulation... 2003]. Its main premise was inclusion of all inhabitants in the waste collection system. This was related to the creation of conditions for selective collection of municipal waste, with special attention given to packaging waste, glass, paper and cardboard, plastic and hazardous waste.

Owners of real properties fulfilling the obligation of collecting municipal waste, and therefore, 
also municipal waste discharge, were required to document the discharge via: - concluding an agreement with a discharge company; - confirming collection of municipal waste; - confirming payment for the waste collection service for the discharge company.

\section{Analysis of system changes in municipal waste management from 1 July 2013}

After the introduction of changes in waste management, the entity responsible for organisation and functioning of the new system was the Łososina Dolna County, which was made liable for:

- selection of a discharge company via a tender procedure;

- conclusion of an agreement with a selected service contractor;

- including all inhabitants of the county under the waste collection system;

- ensuring accomplishment of required waste recovery and recycling levels;

- ensuring financing for waste discharge for the purpose of waste management according to the criteria resulting from the local law [Regulation..., 2013].

In relation to the introduced changes, the county additionally introduced the collection of bio-degradable waste and ash via a Collection Station of Selective Municipal Waste, generally available for the inhabitants. Such system solution is conducive to sustainable development [Devadula, 2015]. The frequency of municipal waste collection in two analysed periods was identical and took place twice a month, with the exception of large-size waste and used electric and electronic equipment.

\section{ANALYSIS OF RESULTS}

The number of inhabitants in the Lososina Dolna County between 2012 and 2014 ranged between 10603 and 10742 (Table 1). The number of inhabitants registered for permanent and temporary residence in the county in 2012 was 10 603, whereas the number of households included in the waste management system was 2401. Increase in the number of residents and households was observed in the subsequent two years by 347 persons and 117 households on average.

The total quantity of municipal waste collected in the county between 2012 and 2014 ranged from $867.863 \mathrm{Mg}$ to $1028.7 \mathrm{Mg}$ with the average of $949.38 \mathrm{Mg}$ (Table 2). The smallest quantity of waste was collected in 2012 and the greatest in 2013 with an increase in the number of residents by 95 persons and increase in the number of households by 347 . As part of the new system, from 1 July 2013 to 31 December 2013, 441.67 $\mathrm{Mg}$ was collected. On the other hand, with the greatest number of residents in 2014, the total quantity of collected municipal waste amounted to $951.57 \mathrm{Mg}$. In 2014, after introduction of changes in the waste management system, the mass of collected municipal waste grew in comparison to 2012 by $84.00 \mathrm{Mg}$.

The average resident of the analysed county accumulated the smallest amount of municipal waste $(0.23 \mathrm{~kg})$ in 2012 . In 2013, this index amounted to $0.26 \mathrm{~kg} \cdot \mathrm{M}^{-1} \cdot \mathrm{day}^{-1}$ and was the highest in the analysed period. In 2014, the amount of municipal waste per inhabitant of the county dropped by $0.02 \mathrm{~kg}$ in comparison to the previous year and amounted to $0.24 \mathrm{~kg}$ (Figure 1). This confirms an increase in waste accumulation with special attention given to the year 2013.

Table 1. Number of inhabitants and households included under the waste management system in the Łososina Dolna County between 2012 and 2014

\begin{tabular}{|l|c|c|c|}
\hline \multicolumn{1}{|c|}{ Year } & 2012 & 2013 & 2014 \\
\hline Number of households & 2401 & 2748 & 2775 \\
\hline Number of inhabitants with registered addresses & 10603 & 10698 & 10742 \\
\hline
\end{tabular}

On the basis of data of the Central Statistical Office and data from the Łososina Dolna County.

Table 2. Quantity of municipal waste collected in total in the area of the Łososina Dolna County between 2012 and 2014

\begin{tabular}{|c|c|c|c|c|}
\hline \multirow{2}{*}{ Years } & \multirow{2}{*}{2012} & \multicolumn{2}{|c|}{2013} & \multirow{2}{*}{2014} \\
\cline { 3 - 4 } & & 1 January -30 June & 1 July -31 December & \\
\hline Waste quantity $[\mathrm{Mg}]$ & 867.86 & 587.03 & 441.67 & 951.57 \\
\hline
\end{tabular}

On the basis of data of the Łososina Dolna County. 
Non-segregated (mixed) waste had the greatest share $(67.55 \%)$ in the mass of collected municipal waste. During the analysed years, the greatest amount of mixed municipal waste in the commune was collected in 2013, whereas the smallest in 2012 (Table 3). In 2013, in the first half of the year, $410.85 \mathrm{Mg}$ mixed waste was collected, whereas in the second half, the quantity of such waste dropped by 137.69 $\mathrm{Mg}$ and amounted to $273.16 \mathrm{Mg}$. In 2014, the amount of mixed municipal waste generated in the county dropped by $58.00 \mathrm{Mg}$ in comparison to 2013. After changes in 2014, the amount of non-segregated municipal waste amounted to $626.00 \mathrm{Mg}$ and decreased by $15.60 \mathrm{Mg}$ in comparison to 2012 - before the introduction of changes.
In the Lososina Dolna County, the amount of municipal waste collected selectively between 2012 and 2014 ranged from $257.463 \mathrm{Mg}$ to $344.70 \mathrm{Mg}$. The greatest amount of segregated municipal waste was collected in 2013, the smallest in 2012. The level of waste recovery ranged from $30 \%$ to $34 \%$ which confirms an increase in 2013 and 2014 (Figure 2).

With respect to the municipal waste collected selectively, the dominant group on the level of over $23 \%$ was glass packaging. The amount of such waste in the analysed years was subject to significant changes. The smallest share was in 2014, whereas the greatest in 2013. In the second half of 2013, the amount of such waste dropped by $39.96 \mathrm{Mg}$ in comparison to the first half of this year. The mass of glass packaging waste in 2014

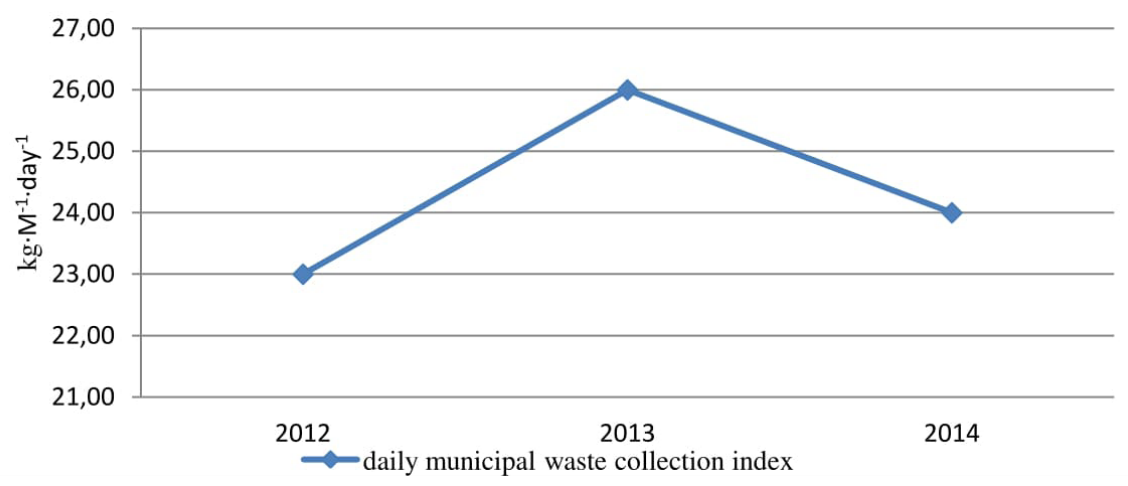

Figure 1. Daily municipal waste collection index in the Łososina Dolna County between 2012 and 2014

Table 3. Quantity of non-selective municipal waste collected in the Lososina Dolna County between years 2012 and 2014

\begin{tabular}{|c|c|c|c|c|}
\hline \multirow{2}{*}{ Waste type } & \multirow{2}{*}{2012} & \multicolumn{2}{|c|}{2013} & \multirow{2}{*}{2014} \\
\hline & & 1January - 30 June & 1 July - 31 December & \\
\hline $\begin{array}{l}\text { Non-segregated (mixed) } \\
\text { municipal waste }[\mathrm{Mg}]\end{array}$ & 610.40 & 410.85 & 273.16 & 626.00 \\
\hline
\end{tabular}

On the basis of data from the Łososina Dolna County.

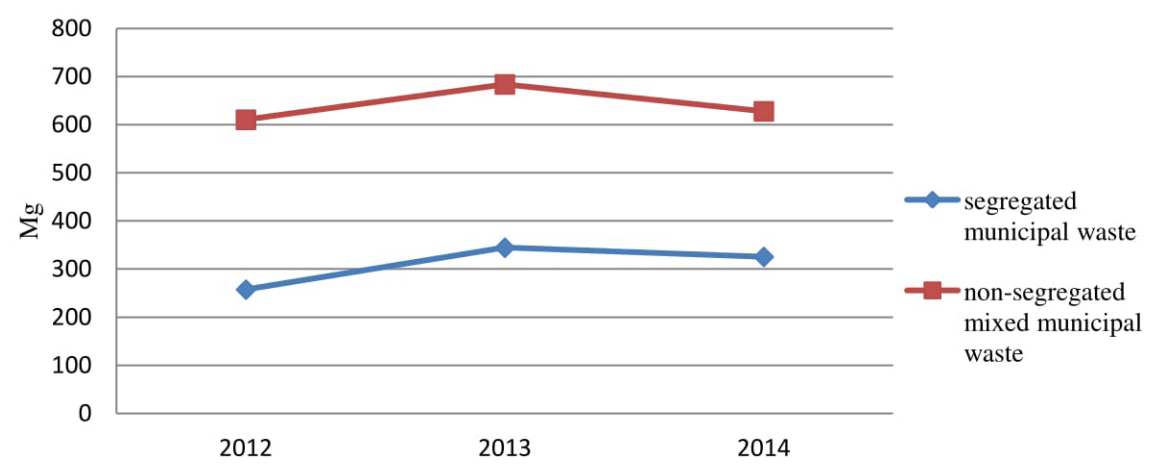

Figure 2. Quantity of non-segregated mixed municipal waste and segregated mixed municipal waste in the area of the Łososina Dolna County between 2012 and 2014 
dropped by 5.28 percentage points in comparison to the year 2012 .

Plastic packaging waste has also a significant share of $6.83 \%$. The largest quantity of plastic packaging was collected in 2014: 92.60 $\mathrm{Mg}$, whereas the smallest in 2012: $27.10 \mathrm{Mg}$, which showed a great increase by $65.50 \mathrm{Mg}$. This type of waste belongs to a dominant group of waste collected in the county with the average annual mass amounting to $64.70 \mathrm{Mg}$. The quantity of plastic packaging in the first half of 2013 grew by $28.78 \mathrm{Mg}$ in comparison to the second half of that year.

The share of paper and cardboard waste, including packaging waste, in the total mass amounts to $1.31 \%$. The slightest amount was collected in 2012 with the mass of $7.20 \mathrm{Mg}$, and the greatest of $15.70 \mathrm{Mg}$ in 2014. In 2013, before the analysed changes in waste management, such quantity amounted to $5.95 \mathrm{Mg}$, whereas in the second half of the year to $8.45 \mathrm{Mg}$, which confirms an increase by $2.50 \mathrm{Mg}$. In 2014, $15.70 \mathrm{Mg}$ paper and cardboard waste was generated, which shows an increase by 0.82 percentage points in comparison to 2012.

In the analysed period, the mass of collected used electric and electronic devices ranged from $4.90 \mathrm{Mg}$ to $5.90 \mathrm{Mg}$. The greatest quantity was recorded in 2012, whereas the smallest in 2014 with a drop by $1 \mathrm{Mg}$. In the first half of 2013, the mass of collected used electric and electronic devices amounted to $3.73 \mathrm{Mg}$, whereas in the $2^{\text {nd }}$ half of the year to $1.17 \mathrm{Mg}$, which also confirms a drop, yet by $2.56 \mathrm{Mg}$. In 2014, the quantity of such waste dropped by $0.95 \mathrm{Mg}$ in comparison to 2012 .

Between 2012 and 2014, the mass of collected products containing CFC ranged from 2.20 $\mathrm{Mg}$ to $2.60 \mathrm{Mg}$. The smallest quantity of such waste was collected in 2014 and in comparison to 2013 , when the quantity of the collected waste was highest, a drop of $0.40 \mathrm{Mg}$ was observed. The share of products containing CFC in the analysed years amounted to $0.25 \%$ in the total mass of collected waste.

Fluorescent lamps and other waste containing mercury had the smallest share $(<0.01 \%)$ in the mass of waste collected in the Lososina Dolna County. In the analysed period, the mass of the above-mentioned waste was within 0.003 $\mathrm{Mg}-0.02 \mathrm{Mg}$. The smallest value was recorded in 2012, and the greatest in 2013. In 2014, the quantity of collected waste grew by $0.007 \mathrm{mg}$ in comparison to the quantity collected in 2012 .
The next group of waste that was collected in the county were batteries. Their mass ranged from $0.06 \mathrm{Mg}$ to $0.10 \mathrm{Mg}$. The smallest quantity of batteries was recorded in 2012. In 2013 and 2013, the values were identical and amounted to $0.1 \mathrm{Mg}$. On the other hand, in the first half of 2013, the mass of collected waste amounted to $0.03 \mathrm{Mg}$, whereas in the second half of the year to $0.07 \mathrm{Mg}$, which confirms an increase by $0.04 \mathrm{Mg}$.

No collection of bio-degradable waste in the area of the county in 2012 resulted from the option of its management by household composting plants [Przydatek 2013]. In the first half of 2013, collection of such waste in the amount of $0.05 \mathrm{Mg}$ was recorded, whereas in the second half of the year in the amount of $8.95 \mathrm{Mg}$, which shows an increase. In 2014, the value grew by $8.50 \mathrm{Mg}$ in comparison to the year 2013. The percentage share of the above-mentioned waste in the total mass of waste in 2014 amounted to $2 \%$, and in 2013 to over $2 \%$.

The quantity of other non-biodegradable waste, including waste from municipal cemeteries ranged from 5.2 $\mathrm{Mg}$ to $14.0 \mathrm{Mg}$ between years 2012 and 2014. On average, the quantity of collected waste amounted to $9.47 \mathrm{Mg}$. The greatest value was recorded in 2014, whereas the smallest in 2013. The mass of such waste in 2014 clearly grew in comparison to 2012 , i.e. by $4.80 \mathrm{Mg}$. The percentage share of waste of this type in 2014 grew by 0.40 percentage points in comparison to 2012 .

Another type of waste collected in the area of the commune in the period of three analysed years was mixed waste of concrete, brick rubble, ceramic materials and elements of interior design. In 2012, waste from this group was not collected, whereas in 2013, the mass of such waste amounted to $0.38 \mathrm{Mg}$ and in 2014 to $0.44 \mathrm{Mg}$, which confirms an increase (Table 4). The share of analysed waste in comparison to waste collected in general did not exceed $0.05 \%$.

\section{DISCUSSION}

There was a general increase in the quantity of collected municipal waste by $10 \%$ between 2012 and 2014 in the area of the county (Figure 3). Such a trend is convergent with the general increase in the quantity of waste generated around the world [Adamcová et al., 2011]. At the same time, an increase in the number of residents by $1.3 \%$ and the number of households by 
Table 4. Quantity of segregated waste collected in the Łososina Dolna County between 2012 and 2014

\begin{tabular}{|c|c|c|c|c|}
\hline \multirow{3}{*}{ Waste type } & \multicolumn{4}{|c|}{ Waste mass [Mg] } \\
\hline & \multirow[b]{2}{*}{2012} & \multicolumn{2}{|c|}{2013} & \multirow[b]{2}{*}{2014} \\
\hline & & $\begin{array}{l}1 \text { July }-30 \\
\text { June }\end{array}$ & $\begin{array}{l}1 \text { July }-31 \\
\text { December }\end{array}$ & \\
\hline Glass packaging & 205.70 & 135.68 & 95.72 & 175.3 \\
\hline Plastic packaging & 27.10 & 22.81 & 51.59 & 92.60 \\
\hline Paper and cardboard (including packaging) & 7.20 & 5.95 & 8.45 & 15.70 \\
\hline Used electric and electronic devices & 5.90 & 3.73 & 1.17 & 4.95 \\
\hline Products containing CFC & 2.30 & \multicolumn{2}{|c|}{2.60} & 2.20 \\
\hline Fluorescent lamps and other waste containing mercury & 0.003 & \multicolumn{2}{|c|}{0.02} & 0.01 \\
\hline Batteries & 0.06 & 0.03 & 0.07 & 0.10 \\
\hline Bio-degradable waste & - & 0.05 & 8.95 & 17.50 \\
\hline $\begin{array}{l}\text { Other non-biodegradable waste, including waste from } \\
\text { municipal cemeteries }\end{array}$ & 9.20 & \multicolumn{2}{|c|}{5.20} & 14.00 \\
\hline $\begin{array}{l}\text { Mixed concrete, brick rubble, ceramic materials and } \\
\text { elements of interior design }\end{array}$ & - & \multicolumn{2}{|c|}{0.38} & 0.44 \\
\hline
\end{tabular}

On the basis of data of the Łososina Dolna County.

$15.6 \%$ was recorded. It is necessary to emphasise that the quantity of generated municipal waste is influenced by a number of factors, mainly socioeconomic ones, which include people's habits and the level of residents' income [Malinowski et al., 2009; Przydatek, 2015]. Mass accumulation of waste shown on the basis of an index has basic evaluative significance. The highest recorded value of such an index of $0.26 \mathrm{~kg} \cdot \mathrm{M}^{-1} \cdot \mathrm{day}^{-1}$, greatly differs from literature data, including the data recorded in Asia [Samah et al., 2013; Generowicz and Gąska, 2014].

Among the collected waste, the greatest share with a clear drop was recorded with respect to non-segregated (mixed) waste with a simultaneous increase in the level of recovered waste by $4 \%$ (Fig. 3). Thanks to the use of recycled materials, pollution of the environment decreases, along with the share of primary materials in production, which saves them and does not lead to the degradation of the landscape [Bien and Bien, 2010]. In the mass of segregated municipal waste, the dominant group on the level of approx. $23 \%$ was glass waste, whose quantity eventually dropped. A similarly dominant share of such waste was confirmed by Przydatek (2013). Packaging waste, according to Rosik-Dulewska (2015), constitutes one of the major problems of municipal waste management. An increase by $6.61 \%$ in the share of municipal waste collected selectively referred to plastic packaging. A similar increase in domestic conditions was shown by Szymańska-Pulikowska (2012). On the other hand, other researchers determine the changed consumption model and resignation from the system of return packaging subject to deposit [Bilitewski et al., 2013] as the cause for the increase of such waste. The share of paper and cardboard waste, including packaging waste below $1.5 \%$ has to be considered low and it diverges from literature data [Żakowska, 2012].

With respect to the used electric and electronic devices and devices containing CFC, there was a decreasing tendency in the quantity of collected waste on the level from $0.16 \%$ to $15 \%$ in the analysed years. A slight increase referred to the fluorescent light waste and other waste containing mercury. The mass of collected batteries was also subject to a slight increase. This may be caused by difficulties related to the management of used batteries, resulting from various sources of power in multiple areas of life in a broad assortment of devices [Malucha et al., 2008]. Studies on the dependency of variation in the quantity of hazardous waste generated in households were conducted by Chaves and Bitencourt da Silva (2015). On this basis, they showed a dependency between an increase in the level of collected hazardous waste and increase in the environmental awareness of inhabitants, which in the case of the analysed county shows certain deficiencies.

Selective collection in the area of the commune also encompassed bio-degradable waste and non-bio-degradable waste, including waste from municipal cemeteries. In the first case, their share did not exceed $2 \%$ and was not subject to changes, whereas in the second case it showed a slight increase by $0.40 \%$. According to the provisions of the National Waste Management Plan (2014), waste subject to bio-degradation constitutes a significant portion of the municipal waste. 


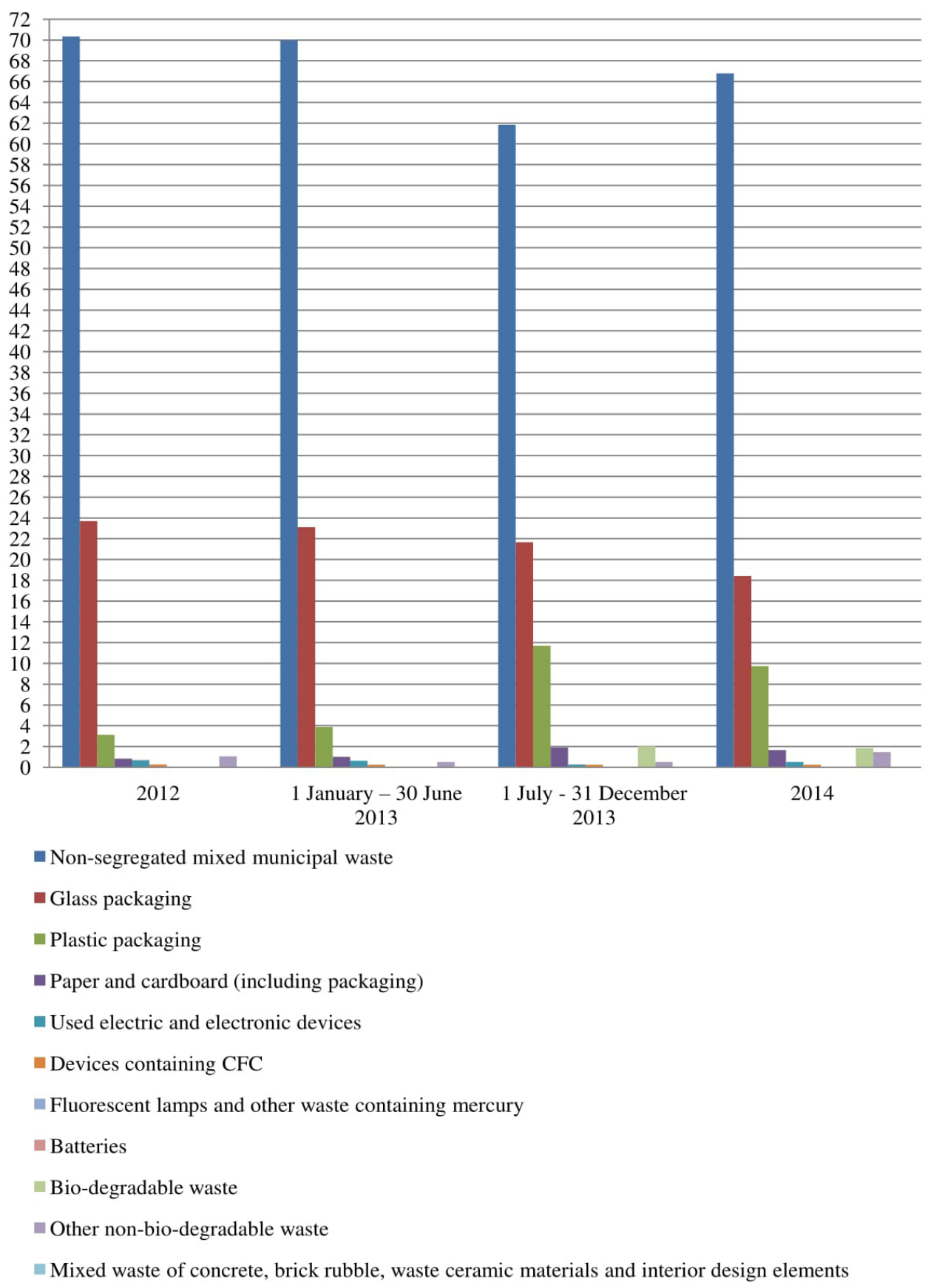

Figure 3. Percentage share of individual types of municipal waste collected selectively and non-selectively in the area of the Łososina Dolna County between 2012 and 2014

The increase also referred to collected mixed waste of concrete, brick rubble, ceramic waste and interior design elements which exceeded $15 \%$ with its slight share in the waste mass below $0.05 \%$. Collection of such waste is important on account of recycling objectives on the level of $50 \%$ of waste from households and $70 \%$ of construction and disassembly waste until 2020 determined in Directive 2008/98/EC of 19 November 2008 on waste repealing certain directives [Official Journal L 312/3 of 2008].

\section{CONCLUSIONS}

On the basis of the analysis with respect to system changes in the management of municipal waste in the area of the Łososina Dolna County, it is possible to draw the following conclusions:

1. The county has become an entity responsible for organisation and supervision over the fulfilment of obligations by waste producers in the area of municipal waste management, starting from waste accumulation. 
2. After introduction of changes in waste management, the general mass of collected municipal waste grew by $10 \%$, along with a growth in the number of inhabitants by $1.3 \%$ and residential buildings by $15.6 \%$.

3. After the changes, a slow increase in the level of waste recovery with the characteristics of recycled materials on average by $4 \%$ has been perceptible, including plastic waste, paper and cardboard, batteries, waste from fluorescent lamps, subject to bio-degradation and mixed construction waste.

4. A drop in the level of collected waste (in comparison to waste in total) included waste collected non-selectively $(8.5 \%)$ and selective waste (from 0.16 to $5.28 \%$ ), glass packaging waste, used electric and electronic devices and devices containing $\mathrm{CFC}$; this may result from incomplete awareness of the inhabitants, as far as environmental threats are concerned.

5. The highest daily waste accumulation index amounted to $0.26 \mathrm{~kg} \cdot \mathrm{M}^{-1} \cdot \mathrm{day}^{-1}$ and is considered quite low.

6. Non-segregated (mixed) municipal waste has the greatest share in the collected waste $(67.77 \%)$, whereas the smallest are selectively collected fluorescent light waste and other waste containing mercury $(<0.01 \%)$.

\section{REFERENCES}

1. Adamcová D., Vaverková M. D., Stejskal B., Břoušková E., 2016. Household Solid Waste Composition Focusing on Hazardous Waste. Pol. J. Environ. Stud. Vol. 25, No. 2, 487-493.

2. Bergel T., Kaczor G., 2006. Szacowana a rzeczywista ilość odpadów komunalnych zbieranych w gminach wiejskich. Infrastruktura i Ekologia Terenów Wiejskich. No. 3/2/2006, 5-16.

3. Bień B., Bień J.D., 2010. Gromadzenie i selektywna zbiórka odpadów komunalnych w gminach. Inżynieria i Ochrona Środowiska, vol. 13, No. 3, 173-183.

4. Biegańska J., Ciuła J. 2011. Zintegrowane systemy gospodarki odpadami. Archiwum Gospodarki Odpadami i Ochrony Środowiska ISSN 1733-4381, Vol. 13 No. 1, 51-60.

5. Bilitewski B., Hardtle G., Marek, K., 2003. Podręcznik gospodarki odpadami. Warsaw: Wydawnictwo "Seidel-Przywecki” Sp. z o.o., $1-734$.
6. Chaves A.P.L., Bitencourt da Silva R., 2015. Environmental diagnosis of hazardous household wastes and the family health strategy as liaison for implementation of a management program in the South of Brazil. Cad. Saúde Colet., Rio de Janeiro, 23 (2), 109-117.

7. Devadula S., Gurumoorthy B., Chakrabarti A., 2015. Design for sustainability: case of designing an urban household organic waste management system. Current Science, Vol. 109, No. 9, 10, 1622-1629.

8. Directive 2008/98/EC of 19 November 2008 on waste and repealing certain Directives (Official Journal No. L 312/ 3 of 2008).

9. Generowicz A, Gąska K., 2014. Research on waste generation indicators for 40 thousand inhabitants community. Archiwum Gospodarki Odpadami i Ochrony Środowiska, ISSN 1733-4381, Vol. 16, issue 2, 67-74.

10. Gmina Łososina Dolna. 2015. Collected Decmber 12, 2015 from locations website of the Lososina Dolna County: http://www.lososina.pl/pl/79301/0/ NASZA_GMINA.html

11. National Waste Management Plan. (2014), 1-166

12. Kwapisz, J. 2003. Gospodarka odpadami komunalnymi w gminie Gródek n. Dunajcem. Infrastruktura i Ekologia Terenów Wiejskich No. 3/2005, 83-93.

13. Malinowski Krakowiak-Bal A., Sikora J., Woźniak A., 2009. Ilość generowanych odpadów komunalnych w aspekcie typów gospodarczych gimn województwa małopolskiego. Infrastruktura i Ekologia Terenów Wiejskich No. 9/2009, 181-191.

14. Malucha K. Sikora J., Woźniak A., Zemanek J., 2008. Problem gospodarki odpadami niebezpiecznymi w kontekście zużytych baterii., Infrastruktura i Ekologia Terenów Wiejskich No. 8/2008, 135-141.

15. Mohd Armi Abu Samah1, Latifah Abd Manaf1, Amimul Ahsan, Wan Nor Azmin Sulaiman, P. Agamuthu, Jeffrey Lawrence D'Silva, 2013. Household Solid Waste Composition in Balakong City, Malaysia: Trend and Management, Pol. J. Environ. Stud. Vol. 22, No. 6, 1807-1816.

16. Leboda, R. i Oleszczuk, P. 2002. Odpady komunalne $\mathrm{i}$ ich zagospodarowanie. Wydawnictwo UMCS, $1-37$.

17. Przydatek G., 2012. Analiza zmian systemowych w gospodarce odpadami komunalnymi na szczeblu gminnym. Autobusy No. 10, 109-114.

18. Przydatek G., 2013. Ocena wielkości selektywnej zbiórki odpadów na przykładzie wybranej gminy. Infrastruktura i Ekologia Terenów Wiejskich No. 3/III/2013, 209-218. 
19. Przydatek G., 2015. Analysis of logistic systems of the management of the municipal waste of communes on the area chosen in the context of the sustainable development. Logistyka - Nauka Nr 3/2015, 4029-4036.

20. Rakoczy B., 2013. Utrzymanie czystości i porządku w gminie w prawie polskim. LexisNexis, 1-14.

21. Regulations on Cleanness and Order in the Łososina Dolna County of 10 October 2003.

22. Regulations on Cleanness and Order in the Łososina Dolna County of 28 December 2012.
23. Rosik-Dulewska, C. 2015. Podstawy gospodarki odpadami. Warsaw: Wydawnictwo Naukowe PWN, pp. 390.

24. Szymańska-Pulikowska A., 2012. Współczesne problemy w planowaniu gospodarki odpadami. Infrastruktura i Ekologia Terenów Wiejskich No. 3/ III/2012, 209-220.

25. Żakowska H., 2012. Systemy recyklingu odpadów opakowaniowych - wybrane problemy prawnoorganizacyjne i ekonomiczne w Polsce. Polimery No. 9 vol. LVII, 611-694. 